\title{
OPTIMIZATION ANALYSIS OF PLANT LANDSCAPES IN TANDAI IRRIGATION AREA, KERINCI DISTRICT, JAMBI
}

\author{
Acep Hidayat \\ Faculty of Engineering \\ University Mercu Buana Jakarta, Indonesia \\ Acep_hidayat@mercubuana.ac.id \\ Marcellino Rico Ariana \\ Faculty of Engineering \\ University Mercu Buana Jakarta, Indonesia \\ Marcellinorico.mr@gmail.com
}

\begin{abstract}
The Plantation Network has a land area of 375 ha. Population which is directly proportional to the necessities of life, one of which is in the food sector, has made the government take the initiative to meet the needs and welfare of the community with productive agricultural land and fields. The data includes secondary data on 10-year rainfall from Depati Parbo and Kayu Aro Station, and 10-year climatology from Kayu Aro Climatology Station. The calculation method used is the rainfall intensity Average method, Evapotranspiration modification Penman method, Debit danalan DR.FJ Mock method, cropping patterns, and irrigation water needs. Related to the calculation of 6 alternative cropping patterns with different types of plants and different initial planting plans by making comparisons with the existing discharge factor (Q80). Obtained that the cropping pattern is very possible, namely using the cropping pattern PADI-PADI-PALAWIJA. The most efficient and optimal planting pattern is that this cropping system consists of PADI-PADI-ON with a large water demand in tertiary plots (NFR tertiary plots) producing 0 - 1,308 ltr / dt / ha with a maximum of 1,308 Itr / ha / February II, while the need for irrigation water in the intake (DR intake) ranges from $0-1,615 \mathrm{ltr} \mathrm{sec} /$ ha with a maximum of 1,615 Itr / sec / ha in February II. The available debit and debit in the Irrigation Network Planning Mark is very abundant with the mainstay discharge (Q80) for irrigation, the maximum available debit (Q80) can occur in November with 202,207 ltr / sec / ha and the minimum in August with 115,012 Itr / sec / $\mathrm{Ha}$. Based on the results of the discharge and water above, it can be determined about the ratio of water / air equilibrium between discharge and water Q80 and the need for irrigation water requires a large / adequate surplus.
\end{abstract}

Keywords: Planting pattern, Marking irrigation network, Mainstay

\section{INTRODUCTION}

Population growth is directly proportional to the increasing needs of life, one of which is the food sector. To meet the increasing food needs, the Kerinci Regency Government cleared forest land into productive fields and fields in several villages within its area. In this connection, an integrated irrigation system is needed to meet the water needs of plants in the area.

One of the priority uses of water resources in Kerinci Jambi Regency is irrigation water sources, both from rivers and springs. The availability of water resources to fulfill irrigation in Kerinci Regency shows that the water source is still sufficient to serve the rice fields in Kerinci Regency Jambi.

To enable the creation of intensive paddy fields and the optimal use of irrigation network facilities and infrastructure, besides requiring a balance of the quantity of water resources, land and human resources, a formidable agricultural actor, information is also needed on establishing effective cropping patterns in accordance with agricultural conditions in the Irrigation Area Mark currently, which is related to the planting schedule, planting area, so that the most efficient irrigation water needs are obtained. 
Identification of the problem is an alternative cropping pattern proposed to obtain the effectiveness of irrigation water requirements, the most optimal cropping pattern in the Irrigated Area of the Irrigation Area, how much is the need for irrigation water in the Tandai Irrigation area.

The purpose of this study is to obtain an alternative picture of cropping patterns in the Tanda irrigation area, establish optimal cropping patterns and maximize agricultural land that can be irrigated with more effective and efficient patterns, find out the irrigation water needs in the Tandai Irrigation area.

\section{RESEARCH METHODOLOGY}

This study uses a research method with a case study approach, where the method used is descriptive quantitative and analytical aiming to evaluate conditions at a certain period as a basis for planning for the future based on data that has been collected, based on theoretical and empirical analysis which then draws conclusions from the results of the analysis that has been done.

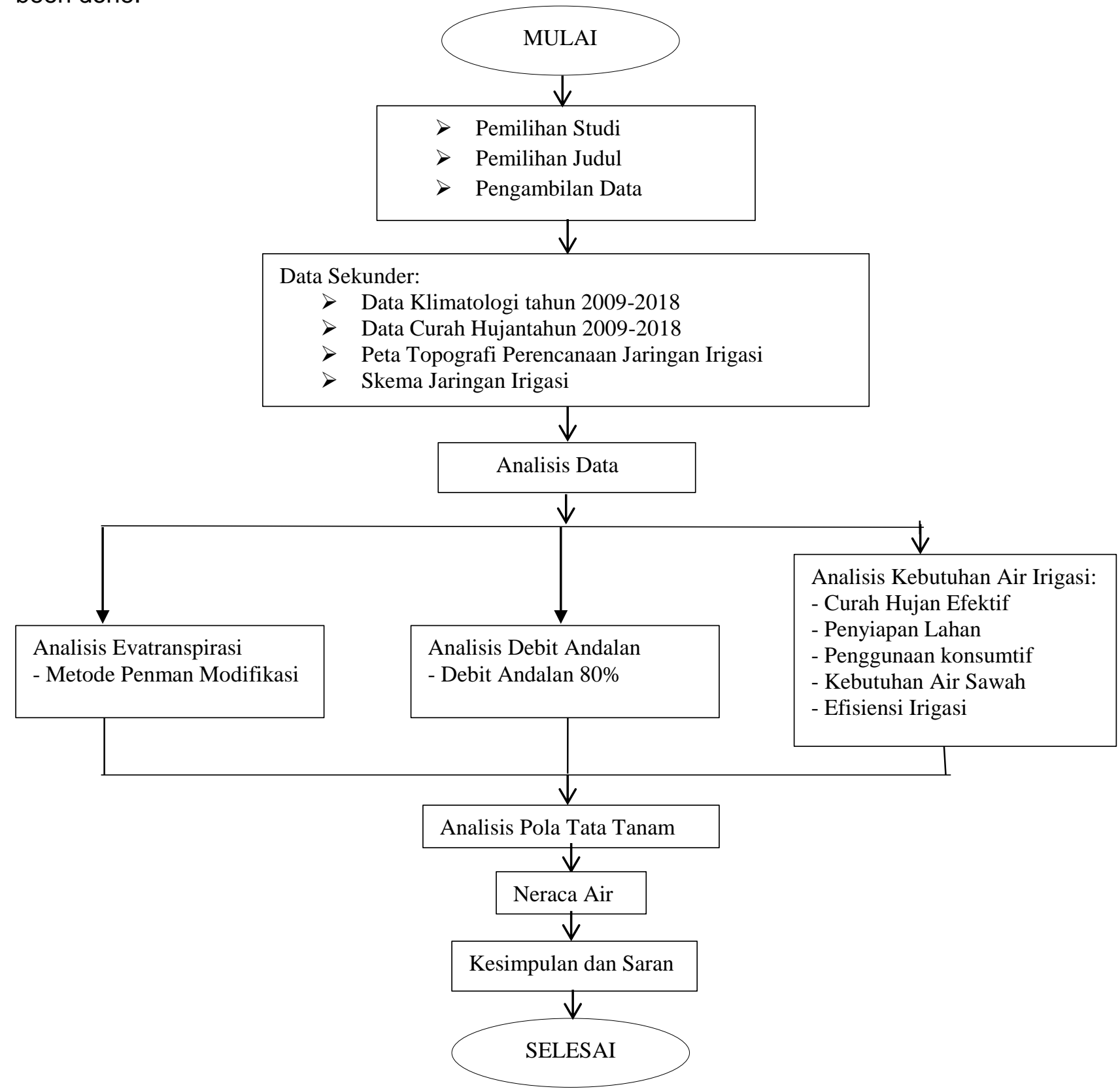




\section{RESULTS AND DISCUSSIONS}

- $\quad$ Maximum Rainfall and Finding Missing Data

Obtain maximum rainfall data for the Depati Parbo and Kayu Aro areas with 2 periods per month. There was missing data in May 2013 in the Depati Parbo area, so the missing data was searched in the following way:

a) Calculation of data missing Depati Parbo Rainfall May 2013 period I:

$\mathrm{dx} \quad=1 / 2 \times(24 / 25,05) \times 29,34$

$=14,06 \mathrm{~mm} /$ day

b) Calculation of data missing Depati Parbo Rainfall May 2013 period II:

$\mathrm{dx}=1 / 2 \times(32 / 33,6) \times 27,69$

$=13,19 \mathrm{~mm} /$ day

- Mainstay Rainfall

Looking for Rainfall Mainstay per month 2 periods:

$\mathrm{R} 80=\mathrm{n} / 5+1$

$=(10 / 5)+1=3$

So that the smallest data obtained for R80, so the data can be in the Figure as follows:

CURAH HUJAN ANDALAN R80 PER 2 PERIODE

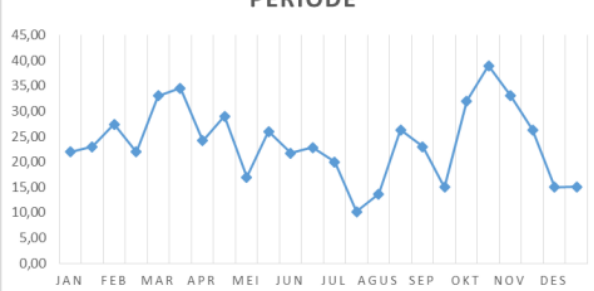

In this graph it can be concluded that the mainstay rainfall (R80) was mostly found in October period 2 and March period 2, while the few were in July period 2, August period 1, September period 2, and December periods 1 and 2.

- $\quad$ Effective Rainfall

Effective rainfall using the Basic Years method in the first January period 1 is calculated by the analysis of the formula as follows:

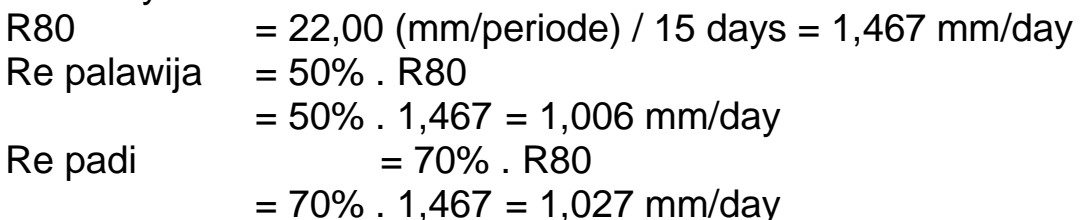

\begin{tabular}{|c|c|c|c|c|c|c|}
\hline Bulan & $\begin{array}{c}\text { Juml } \\
\text { ah } \\
\text { Hari }\end{array}$ & $\begin{array}{c}\text { R80 } \\
\text { (mm/period } \\
\text { e) }\end{array}$ & $\begin{array}{l}\operatorname{Re80}(\mathrm{m} \\
\mathrm{m} / \mathrm{hari})\end{array}$ & $\begin{array}{c}\text { Re Padi } \\
(\mathrm{mm} / \mathrm{har} \\
\text { i) }\end{array}$ & \begin{tabular}{|c} 
Re \\
Palawij \\
$\mathbf{a}$ \\
$(\mathbf{m m} / \mathbf{h a}$ \\
$\mathbf{r i})$
\end{tabular} & 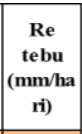 \\
\hline \multirow{2}{*}{ Januari } & 15 & 22,000 & 467 & 1,027 & 0,733 & 0,88 \\
\hline & 16 & 3,000 & 1,438 & 1,006 & 0,719 & 0,8625 \\
\hline \multirow{2}{*}{ Februari } & 15 &, 46 & 827 & 1.279 & 0,913 & 1,096 \\
\hline & 13 & 22 & 92 & 1,185 & 0,846 & 1,0154 \\
\hline \multirow{2}{*}{ Maret } & 15 & 3,000 & 00 & 1,540 & 1,100 & 1,32 \\
\hline & 16 & 5 & 6 & 509 & 1,078 & 1,2938 \\
\hline \multirow{2}{*}{ April } & 15 & & & 1,129 & 0,807 & 0,968 \\
\hline & 15 & & & 1353 & 0,967 & 1,16 \\
\hline \multirow{2}{*}{ Mei } & 15 & 1 & 33 & 0,793 & 0,567 & 0,68 \\
\hline & 16 & & & & 0,813 & 0,975 \\
\hline \multirow{2}{*}{ Juni } & 15 & & & 3 & 0,723 &, 868 \\
\hline & 15 & 2 & - & 34 & 0,760 & 0,912 \\
\hline & 15 & & & & 0,667 & 0,8 \\
\hline & 16 & & & & 0,319 &, 3825 \\
\hline \multirow{2}{*}{ Agustus } & 15 & 13,700 & 913 & 0,639 & 0,457 & 0,548 \\
\hline & 16 & & & & 0,822 & 0,9863 \\
\hline \multirow{2}{*}{ September } & 15 & 2 & & 13 & 0,767 & 0,92 \\
\hline & 15 & & & & 0,500 & 0,6 \\
\hline \multirow{2}{*}{ ktobe } & 15 & & & 1,493 & 1,067 & 1,28 \\
\hline & 16 & & & & 1,219 & 1,4625 \\
\hline \multirow{2}{*}{ November } & 15 & 0,0 & 2,200 & 1,540 & 1,100 & 1,32 \\
\hline & 15 & & & 1,227 & 0,877 & 1,052 \\
\hline \multirow[b]{2}{*}{ Desember } & 15 & & & 0,700 & 0,500 & $=$ \\
\hline & 16 & 5,100 & 0,944 & 0,661 & 0,472 & 0,56 \\
\hline
\end{tabular}




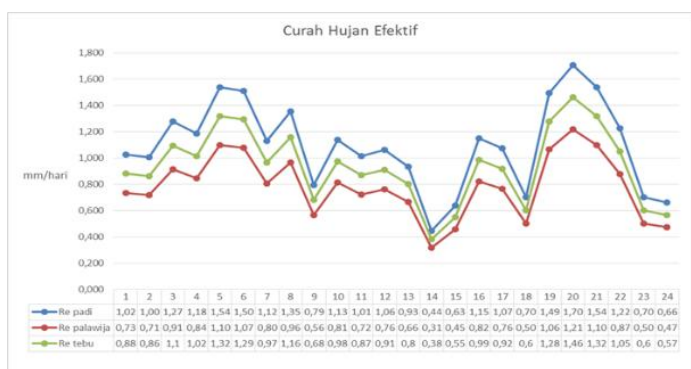

From this graph it can be seen that the effective rainfall for rice (Re-paddy) is the largest, and the effective rainfall for the smallest (Re-cropping). The greatest effective rainfall is in the 20th or October period 2, while the smallest effective rainfall is in the 14th or July period 2.

- $\quad$ Calculate Evapotranspirasi Potensial (ETo)

The method used here is the Penman Modification method because the climatology data is quite complete. Here are the results for Evapotranspirasi (ET0):

Calculate $E$ (Evaporasi) of the value b sought for es (saturated water vapor pressure) and ed (Water vapor pressure at elevation $2 \mathrm{~m}$ above surface) and value $\mathrm{B}$ :

es $\quad=611 \exp ((17,27 \mathrm{~T}) /(237,3+\mathrm{T}))$

$=611 \exp ((17,27 \times 22,283) /(237,3+22,283))$

$\mathrm{B}=0,102 \mathrm{u} 2 /(\ln \sigma(\mathrm{z} 2 / \mathrm{ZO})) 2$

$=0,102 \times 2 /(\ln =2690,71$ Pascal

ed $\quad=$ es $\times r$ (humidity)

$=2690,71 \times 92,81 \%$

$=2497,336$ Pascal

$=18,71 \mathrm{mmHg}$

$(5 / 200)) 2=0,023$

$\mathrm{E}=\mathrm{B}(\mathrm{es}-\mathrm{ed})$

$=0,023 \times(2690,71-2497,336)$

$=4,434 \mathrm{~mm} /$ day

Coordinate $\quad=1040$ '15" LS

$=(1+40 / 60+15 / 3600)$ o LS

$=1,671$ o LS

The calculated St (Radiasi matahari bruto yang diserap permukaan bumi):

St $=\mathrm{S} 0(\mathrm{a}+(\mathrm{b} \times \mathrm{n} / 12,1))$

$=885 \times(0,29+(0,42 \times 3,388 / 12,1)=360,721$

The calculated Sn (Radiasi matahari netto yang diserap permukaan bumi ) by formula below:

Sn $=$ St $(1-\alpha)$

Value $\alpha=0,20$ taken from Tabel Nilai $\alpha$ (albedo) in the form of plant surface types.

$\mathrm{Sn}=360,721 \times(1-0,20)$

$=288,57(\mathrm{cal} / \mathrm{cm} 2 /$ day $)$

The calculated Ln (Radiasi gelombang panjang yang dipancarkan bumi) by formula below:

Ln $\quad=\sigma T 4(0,56-0,092$ Ved $)(0,1+0,9 \mathrm{n} / \mathrm{N})$

$=1,17.10-7 \times 295,284 \times(0,56-0,092 \sqrt{ } 18,71) \times(0,1+0,93,388 / 12,1)$

$=50,738(\mathrm{cal} / \mathrm{cm} 2 /$ day $)$

The calculated Rn (Radiasi netto) by formula:

$\mathrm{Rn}=\mathrm{Sn}-\mathrm{Ln}$

$=288,57-50,738=237,839(\mathrm{cal} / \mathrm{cm} 2 /$ day $)$

The calculated Iv (Panas laten untuk evaporasi) by formula below:

Iv $\quad=597,3-0,56 \mathrm{~T}$

$=597,3-(0,56 \times 295,283)$

$=584,733(\mathrm{kal} / \mathrm{gram})$

The calculated En (Kedalaman penguapan) by formula below:

En $\quad=\mathrm{Rn} /(\rho \mathrm{lv})$

$=237,839 /(1 \times 584,733)$

$=0,407(\mathrm{~mm} /$ hari $)$ 
The calculated Evapotranspirasi Potensial (ET0) by formula below:

ETO = $(\beta E n+E) /(\beta+1)$

Value $\beta$ obtained from interpolation at Tabel 4.12. Ie temparature $22,2830 \mathrm{C}$ so $\beta$ with interpolation is 2,496 .

$$
\begin{aligned}
\text { ETO } & =((2,496 \times 0,407)+4,434) /(2,496+1) \\
& =4,172(\mathrm{~mm} / \text { hari }) \\
& \text { Land Preparation }
\end{aligned}
$$

Calculation of water requirements for land preparation is done by the Van de Goor Zijlstra method. This method is based on the need for water to replace water losses due to evaporation and percolation in paddy fields that have been saturated for 30 days with a high inundation of $250 \mathrm{~mm}$, or $8.33 \mathrm{~mm} /$ day. Calculating land preparation in January. Known in January:

Perkolasi $=2 \mathrm{~mm} /$ day

Et0 $\quad=4,172$

$\mathrm{M} \quad=\mathrm{E} 0+\mathrm{P}=1,1 \mathrm{ETO}+\mathrm{P}$

$=1,1 \mathrm{ET} 0+\mathrm{P}$

$=(1,1 \times 4,172)+2$

$=6,590$

$\mathrm{Pd}$

$$
\begin{aligned}
& =\llbracket \mathrm{Me}]^{\wedge} \mathrm{k} /\left(\mathrm{e}^{\wedge} \mathrm{k}-1\right) \\
& =\llbracket(6,590.2,718]^{\wedge}(6,590 \times 31 / 250) /\left(\left[2,718 \rrbracket^{\wedge}(6,590 \times 31 / 250)-1\right)\right.
\end{aligned}
$$$$
=\llbracket 6,590.2,718 \rrbracket^{\wedge} 0,817 /\left(\left(2,718 \rrbracket^{\wedge} 0,817-1\right)\right.
$$

$=11,804 \mathrm{~mm} /$ day

\begin{tabular}{|c|l|c|c|c|c|c|c|c|c|c|c|c|c|c|}
\hline \multirow{2}{*}{ No. } & Perhitungan & Satuan & Jan & Feb & Mar & Apr & Mei & Juni & Juli & Agst & Sep & Olt & Nov & Des \\
\hline 1 & Eto & mm/hari & 4,172 & 4,667 & 4,552 & 4,467 & 3,849 & 3,358 & 3,632 & 4,235 & 8,645 & 3,158 & 4,012 & 3,830 \\
\hline 2 & E0=1,1 xEto & mmhari & 4,590 & 5,134 & 5,008 & 4,913 & 4,234 & 3,694 & 3,996 & 4,659 & 9,509 & 3,474 & 4,414 & 4,212 \\
\hline 3 & P & mmhari & 2,00 & 2,00 & 2,00 & 2,00 & 2,00 & 2,00 & 2,00 & 2,00 & 2,00 & 2,00 & 2,00 & 2,00 \\
\hline 4 & M =E0 +P & mmhari & 6,590 & 7,134 & 7,008 & 6,913 & 6,234 & 5,694 & 5,996 & 6,659 & 11,509 & 5,474 & 6,414 & 6,212 \\
\hline 5 & T & hari & 31 & 28 & 31 & 30 & 31 & 30 & 31 & 31 & 30 & 31 & 30 & 31 \\
\hline 6 & $\mathrm{~S}$ & $\mathrm{~mm}$ & 250 & 250 & 250 & 250 & 250 & 250 & 250 & 250 & 250 & 250 & 250 & 250 \\
\hline 7 & $\mathrm{k}=\mathrm{MxT} / \mathrm{S}$ & & 0,817 & 0,799 & 0,869 & 0,830 & 0,773 & 0,683 & 0,743 & 0,826 & 1,381 & 0,679 & 0,770 & 0,770 \\
\hline 8 & $\mathrm{e}$ & & 2,718 & 2,718 & 2,718 & 2,718 & 2,718 & 2,718 & 2,718 & 2,718 & 2,718 & 2,718 & 2,718 & 2,718 \\
\hline 9 & $\mathrm{e}^{\mathrm{k}}$ & & 2,264 & 2,223 & 2,384 & 2,292 & 2,166 & 1,980 & 2,103 & 2,283 & 3,979 & 1,971 & 2,159 & 2,160 \\
\hline 10 & $\mathrm{e}^{\mathrm{k}}-1$ & & 1,264 & 1,223 & 1,384 & 1,292 & 1,166 & 0,980 & 1,103 & 1,283 & 2,979 & 0,971 & 1,159 & 1,160 \\
\hline 11 & $\mathrm{Pd}$ & mmhari & 11,804 & 12,967 & 12,070 & 12,263 & 11,580 & 11,503 & 11,431 & 11,848 & 15,373 & 11,110 & 11,948 & 11,566 \\
\hline
\end{tabular}

- Kebutuhan Air Konsumtif

Consumptive use is the amount of water used by plants for the photosynthesis process of these plants. In the calculation of consumptive water needs this time used the calculation of the most efficient cropping patterns, namely alternative planting patterns 1 in November to I.

Etc $=$ Kc .Eto

Rasio Luas ETc $=0,25$

$$
=(0,55) \times 4,012=2,207 \mathrm{~mm} / \text { hari }
$$

ETc $\times$ Rasio Luas ETc $=2,207 \times 0,25=0,552 \mathrm{~mm} /$ hari

Kebutuhan air konsumtif (ETc) in November to I can be presented in the following table::

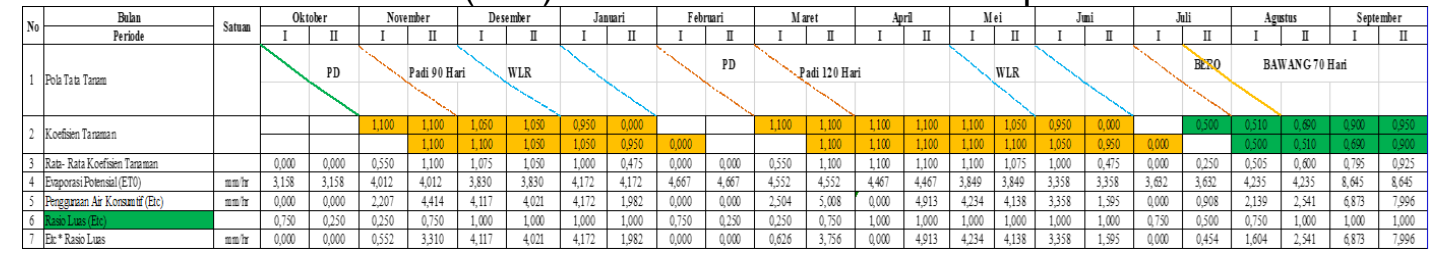

- $\quad$ Kebutuhan Air Irigasi dan Efisiensi Irigasi

Kebutuhan air irigasi merupakan jumlah volume air yang diperlukan untuk memenuhi kebutuhan evapotranspirasi, kehilangan air, kebutuhan air untuk tanaman dengan memerhatikan jumlah air yang diberikan oleh alam melalui hujan dan kontribusi air tanah. (Gunadarma, 1995:20).

Calculate kebutuhan air irigasi (NFR) can be done with formula: 


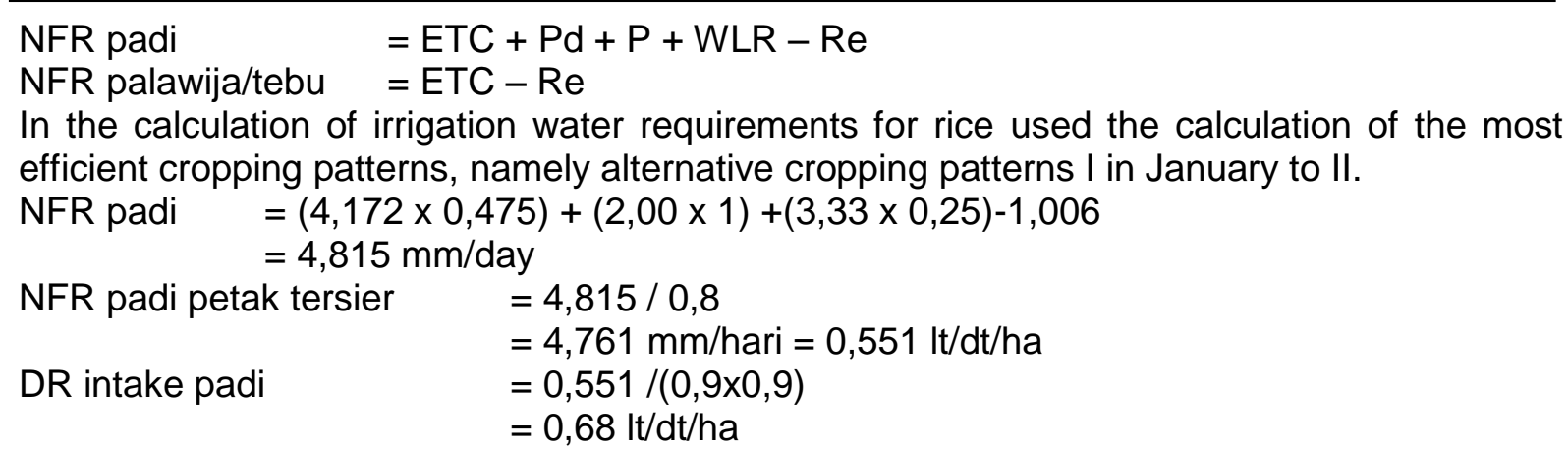

In the calculation of irrigation water needs for secondary crops used the calculation of the most efficient cropping patterns, namely alternative cropping patterns I in August to I.

NFR palawija $=(0,505 \times 4,235)+(2,139 \times 0,75)-0,457$

$$
=1,604 \mathrm{~mm} / \text { hari }
$$

NFR palawija petak tersier $=1,604 / 0,8$

DR intake palawija

$$
\begin{aligned}
& =1,434 \mathrm{~mm} / \text { hari }=0,166 \mathrm{It} / \mathrm{dt} / \mathrm{Ha} \\
& =0,166 /(0,9 \times 0,9) \\
& =0,205 \mathrm{It} / \mathrm{dt} / \mathrm{ha}
\end{aligned}
$$

- Perhitungan Debit Andalan

The data or assumptions used in the FJ Mock calculation are:

10 yearly Rainfall Data with rainfall stations which are considered to represent the condition of the area. The data needed is:a) d rata-rata : Rata-rata curah hujan 10 tahunan

b) $n \quad$ : The average number of rainy days is 10 years

Calculate the average rainfall and number of 10 yearly average rainy days in the Depati Parbo area in January.

$$
\begin{aligned}
\text { D rata } & =(1,22+4,55+6,51+6,01+3,94+5,45+1,57+2,65+3,89+2,88) / 10 \\
& =3,87 \mathrm{~mm} / \text { day } \\
& =(9+16+20+22+20+16+5+12+16+17) / 10 \\
\mathrm{n} \quad & =15,3 \\
\mathrm{D} \text { rata (Kayu Aro + Depati Parbo) } & =(3,87+5,18) / 2 \\
& =4,52 \mathrm{~mm} / \text { day } \\
\mathrm{n} \text { (Kayu Aro + Depati Parbo) } & =(15.3+10,6) / 2 \\
& =12.95
\end{aligned}
$$

B. Evapotranspirasi terbatas adalah actual evapotranspiration by comparing the condition of vegetation and soil surface and rainfall frequency.

a) Evapotranspirasi (ET0) using the Penman Modification method ( $\mathrm{mm} / \mathrm{day}$ )

b) The land opening factors used are:

- M $\quad$ 30-50\% for agricultural land processed (taken 40\%)

c) Calculating $E$ in January

E $=$ ET0 $\times(m / 20(18-n))$

$=4,172 \mathrm{~mm} /$ day $\times(40 \% / 20(18-12,95))$

$=129,34 \mathrm{~mm} /$ month $\times(40 \% / 20(18-12,95))$

$=13,06 \mathrm{~mm} /$ month

d) Limited evapotranspirasi

$\mathrm{E} 1=\mathrm{ET0}-\mathrm{E}$

$=129,34-13,06$

$=116,28 \mathrm{~mm} /$ month

C. Calculating Water Balance / water surplus in January:
a) $\mathrm{S}$
$=\mathrm{R}-\mathrm{E} 1$
$=140,27-116,28$
$=23,99 \mathrm{~mm} / \mathrm{month}$
b) Run Off Storm $\quad=10 \% \times R$
$=10 \% \times 140,27$
$=14,027 \mathrm{~mm} /$ month
c) Soil Storage (IS) = S - Run Off Storm 
$=23,99-14,027$

$=9.96 \mathrm{~mm} /$ month

d) Water Surplus $=\mathrm{S}-$ Soil Storage $\mathrm{S}-$ Soil Storage

$$
\begin{aligned}
& =23,99-9,96 \\
& =14,03 \mathrm{~mm} / \text { month }
\end{aligned}
$$

D. Run Off dan Ground Water Storage

a) Run-off coefficient of various catchment conditions (DAS) is $50 \%$ :

b) Infiltrasi (I) =Ws $\times$ I

$=14,03 \times 50 \%$

$=7,015 \mathrm{~mm} /$ month

c) The recession factor for soil flow $(\mathrm{K})$ is obtained from the following explanation:

- 0.5 For normal or normal rain catchment areas

d) Ground water Storage

(GS) $\quad=(0,5 \times \mathrm{I} \times(1+\mathrm{K}))+(\mathrm{K} \times \mathrm{Gsom})$

$$
\begin{aligned}
& =0,5 \times 7,01 \times(1+0,50))+(0,50 \times 12,36) \\
& =11,44
\end{aligned}
$$

e)

$\Delta \mathrm{GS}$

$=\mathrm{GS}-\mathrm{Gsom}$

$=11,44-12,36$

$=-0,92$

f) Base Flow (BF) = Infiltrasi $-\Delta \mathrm{GS}$

$=7,015-(-0,92)$

$=7,94 \mathrm{~mm} /$ month

g) Direct Run Off $(\mathrm{DRO})=$ Water Surplus - Infiltrasi

$=14,03-7,01$

h) Run Off $(\mathrm{RO}) \quad=\mathrm{BF}+\mathrm{DRO}$

$=7,015 \mathrm{~mm} /$ month

$=7,94+7,015$

$=14,95 \mathrm{~mm} /$ month

i) Luas DAS $(\mathrm{km} 2) \quad=12779,47 \mathrm{~km} 2 \times 10000=1277947 \mathrm{Ha}$

j) Debit Andalan $\quad=$ RO $\times$ Luas DAS $\times 1000$ (m3/bulan)

$=14,95 \times 1277947 \times 1000$

$=191032930,50 \mathrm{~m} 3 /$ month

$=71,32 \mathrm{~m} 3 / \mathrm{s}=71323,53 \mathrm{It} / \mathrm{dt} /$

The probability of being fulfilled is set at $80 \%$ (the possibility that the river discharge is lower than the mainstay discharge is $20 \%$ ). That possibility uses calculations

k) $Q$ andalan $80 \%=(0,8 \times$ Debit Andalan $) /($ luas DI $) \mathrm{ltr} / \mathrm{dt} / \mathrm{ha}$

$$
\begin{aligned}
& =0,8 \times 71323,53 / 375 \\
& =152,16 \mathrm{Itr} / \mathrm{dt} / \mathrm{ha}
\end{aligned}
$$

It is known that DR Intake in January is

$$
\text { I) } \begin{aligned}
\text { Neraca air } & =Q \text { andalan } 80 \%-\text { DR intake } \\
& =152,16-0,68 \\
& =151,477 \mathrm{ltr} / \mathrm{dt} / \mathrm{ha} \text { (fulfilled) }
\end{aligned}
$$

- $\quad$ Pola Tata Tanam dan Neraca Air

Planting patterns are the most important way in planting planning. The purpose of holding a planting system is to set the time, place, type and area of plants in the irrigation area. The purpose of the planting system is to utilize irrigation water supplies as effectively and efficiently as possible so that plants can grow well. The biggest factor in cropping patterns can be said to be efficient and optimal is if necessary water is fulfilled by the mainstay discharge (water balance). The following is the calculation of the water balance in the alternative planting system 1 November to 1 .

Diketahui : $\quad$ andalan $80 \% \quad=202,207 \mathrm{ltr} / \mathrm{dt} / \mathrm{ha}$

$$
\text { DR intake } \quad=1,513 \mathrm{ltr} / \mathrm{dt} / \mathrm{ha}
$$

Neraca air $=Q$ andalan $80 \%$ - DR intake 


$$
\begin{aligned}
& =202,207-1,513 \\
& =200,694 \mathrm{Itr} / \mathrm{dt} \cdot \mathrm{ha} \text { (terpenuhi) }
\end{aligned}
$$

In this final project, 6 alternative cropping patterns are made, and based on the water balance, alternative planting system patterns 1 are displayed in Table 4.19, which is the most efficient and optimal planting system.

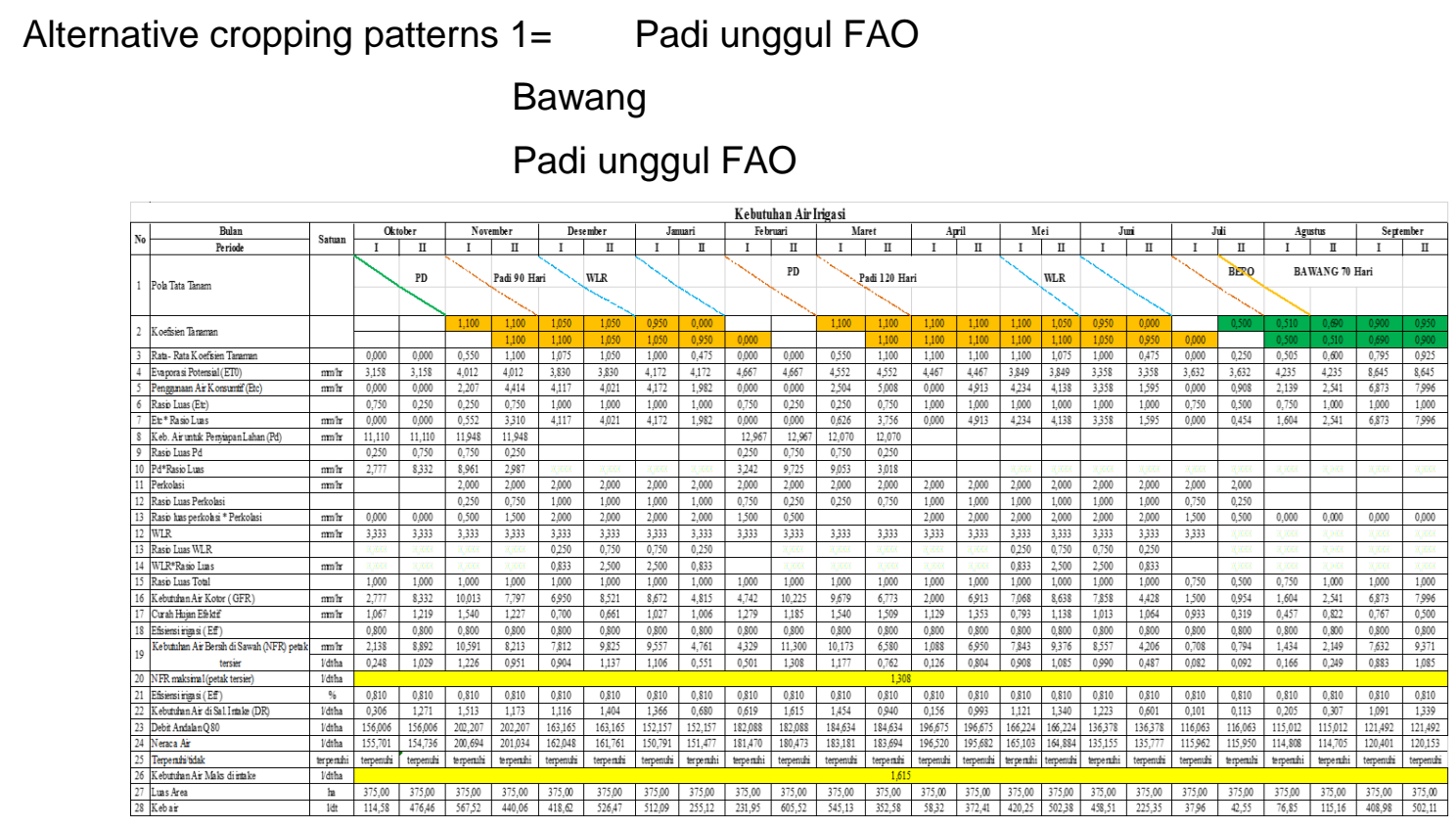

\section{CONCLUSION}

The calculation method used is the rainfall intensity Average method, Evapotranspiration modification Penman method, Debit danalan DR.FJ Mock method, cropping patterns, and irrigation water needs. Related to the calculation of 6 alternative cropping patterns with different types of plants and different initial planting plans by making comparisons with the existing discharge factor (Q80). Obtained that the cropping pattern is very possible, namely using the cropping pattern PADI-PADI-PALAWIJA. The most efficient and optimal planting pattern is that this cropping system consists of PADI-PADI-ON with a large water demand in tertiary plots (NFR tertiary plots) producing $0-1,308 \mathrm{ltr} / \mathrm{dt} /$ ha with a maximum of 1,308 $\mathrm{ltr} /$ ha / February II, while the need for irrigation water in the intake (DR intake) ranges from 0 $1,615 \mathrm{Itr} \mathrm{sec} / \mathrm{ha}$ with a maximum of 1,615 Itr / sec / ha in February II. The available debit and debit in the Irrigation Network Planning Mark is very abundant with the mainstay discharge (Q80) for irrigation, the maximum available debit (Q80) can occur in November with 202,207 Itr / sec / ha and the minimum in August with 115,012 Itr / sec / Ha. Based on the results of the discharge and water above, it can be determined about the ratio of water / air equilibrium between discharge and water Q80 and the need for irrigation water requires a large / adequate surplus.

\section{REFRENCES}

[1] H.R Lagu, A. M., Amansyah, M., \& Mubarak , F. (2015). Public Health Science Journal. Gambaran Penyediaan Air Bersih PDAM Kota Makassar Tahun 2015.

[2] L. Kawet, H. K., \& Halim, F. (2016). Jurnal Sipil Statik. Perencanaan Sistem Jaringan Distribusi Air Bersih Di Kelurahan Pangolombian Kecamatan Tomohon Selatan. 
[3] Lubis, Z., \& Affandi, N. A. (2014). Kebutuhan Air Bersih Di Kecamatan Glagah Kabupaten Lamongan .

[4] Nachshon, U., Netzer, L., \& Livshitz, Y. (2016). Sustainable Cities and Society. Land Cover Properties and Rain Water Harvesting in Urban Environments, 398 - 406.

[5] Nelwan, C., Kekenusa, J., \& Langi, Y. (2013). Jurnal ilmiah sains. Optimalisasi Pendistribusian Air Dengan Menggunakan Metode Least Cust Dan Metode Modified Distribution.

[6] Nugroho, S., Febriamansyah, R., Ekaputra, E. G., \& Gunawan, D. (2019). Jurnal Sumber Daya Air. Simulasi Kebutuhan Air Untuk Tanaman Padi Pada Skenario Perubahan Iklim Didaerah Aliran Sungai Lembang - Sumani.

[7] Nurrohman, F., Eka. P, S. W., Sangkawati, S., \& Sugiyanto. (2015). Jurnal Karya Teknik Sipil. Perencanaan Panen Air Hujan Sebagai Sumber Air Alternatif pada Kampus Universitas Diponegoro, 283 - 292.

[8] Rosmin, N., Jauhari, A. S., Mustaamal, A. H., Husin, F., \& Hassan, M. Y. (2015). Sacient Direct. Experimental study for the single-Stage and Double- Stage TwoBladed Savonius Micro- Sized Turbine for Rain Water Harvesting (RWH) System, 274 $-281$.

[9] Silvia, C. S., \& Safriani, M. (2018). Journal teknik sipil fakultas teknik sipil Universitas Teuku Umar. Analisis Potensi Pemanenan Air Hujan Dengan Teknik Rainwater Harvesting untuk kebutuhan domestik, 62 - 77.

[10] Sumarjo, J., Arbi, A. A., \& Dirja, I. (2017). Jurnal Teknologi. Analisis Dan Perencanaan Kebutuhan Pompa Untuk Memenuhi Kebutuhan Air Bersih PDAM Tirta Tarum Kerawang Cabang Teluk Jambe Sepuluh Tahun Yang Akan Datang.

[11] Susilo, J. J., Dermawan, V., \& Hendrawan, A. P. (2017). Studi Perencanaan Penyediaan Air Bersih Pada Gedung Bertingkat Tunjangan Plasa VI Kota Surabaya.

[12] Venusia, A., Carlo, N., \& Warman, H. (2012). Analisis Ketersediaan Dan Kebutuhan Air Baku Di Kota Sungai Penuh.

[13] Wahyuni, A., \& Junianto. (2017). Aanalisis Kebutuhan Air Bersih Kota Batam Pada Tahun 2025.

[14] Wostl, C. P., Kabat, P., \& Moltgen, J. (n.d.). Groundwater Protections in Urban Areas Incorporating Adaptive Groundwater Monitoring And management - Reconcilitaion of Water Engineering Measures Along Rivers.

[15] Yulistyorini, A. (2011). Teknologi dan kejuruan. Pemamenan Air Hujan sebagai Alternatif Pengelolaan Sumber Daya Air Di Perkotaan, 105 - 114. 